\title{
The effectiveness of cognitive rehabilitation program based on memory on the behavioral problems and working memory in children with hearing impairment
}

\author{
Mohammad Ashori $^{1^{*}}$ (D), Seyyedeh Somayyeh Jalil-Abkenar ${ }^{2}$
}

\begin{abstract}
1. Assistant Professor, Department of Psychology and Education of People with Special Needs, Faculty of Education and Psychology, University of Isfahan, Isfahan, Iran

2. PhD of Psychology and Education of Exceptional Children, Faculty of Psychology and Education, University of Tehran, Tehran, Iran
\end{abstract}

Recieved: 9 Nov. 2018

Revised: 9 Apr. 2019

Accepted: 12 June 2019

Keywords

Cognitive rehabilitation

Behavioral problems

Working memory

Hearing impairment

\section{Corresponding author}

Mohammad Ashori, Department of Psychology and Education of People with Special Needs, Faculty of Education and Psychology, University of Isfahan, Isfahan, Iran

Email: M.ashori@edu.ui.ac.ir

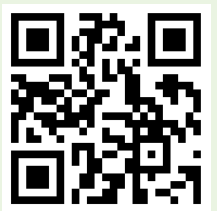

\section{Abstract}

Introduction: Hearing impairment affects all aspects of an individual's life, while applying cognitive rehabilitation program based on memory has been associated with practical outcomes. The present study aimed to determine the effectiveness of cognitive rehabilitation programs based on memory on the behavioral problems and working memory in students with hearing impairment.

Methods: The present research was a semi-experimental study with pre-test, post-test design, and control group. The participants were 26 girl children with hearing impairment from schools in Isfahan city using a convenient sampling method. Subjects were divided into experimental and control groups, each group consisting of 13 children. The experimental group received ten cognitive rehabilitation sessions based on memory, while the control group did not. The instruments were the Child Behavior Checklist (2001) and Working Memory Test Battery for Children (2017). Data were analyzed using MANCOVA.

Results: The results showed that cognitive rehabilitation program based on memory had a significant effect on the behavioral problems and working memory of subjects $(\mathrm{P}<0.0001)$.

Conclusion: According to the findings, cognitive rehabilitation program based on memory improved behavioral problems and working memory in students with hearing impairment. So, this program can be used to improve behavioral problems and working memory of these students and planning for providing a cognitive rehabilitation program based on memory for them is of particular importance.

Citation: Ashori M, Jalil-Abkenar SS. The effectiveness of cognitive rehabilitation program based on memory on the behavioral problems and working memory in children with hearing impairment. Advances in Cognitive Sciences. 2020;22(1):13-24. 


\title{
اثربخشى برنامه توانبخشى شناختى مبتنى بر حافظه بر مشكلات رفتارى و حافظه فعال دانش آموزان با آسيب شنوايى مبنى
}

\author{
محمد عاشورى":(D) ، سيده سميه جليل آبكنار؟
}

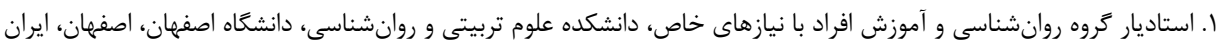

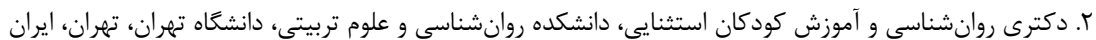

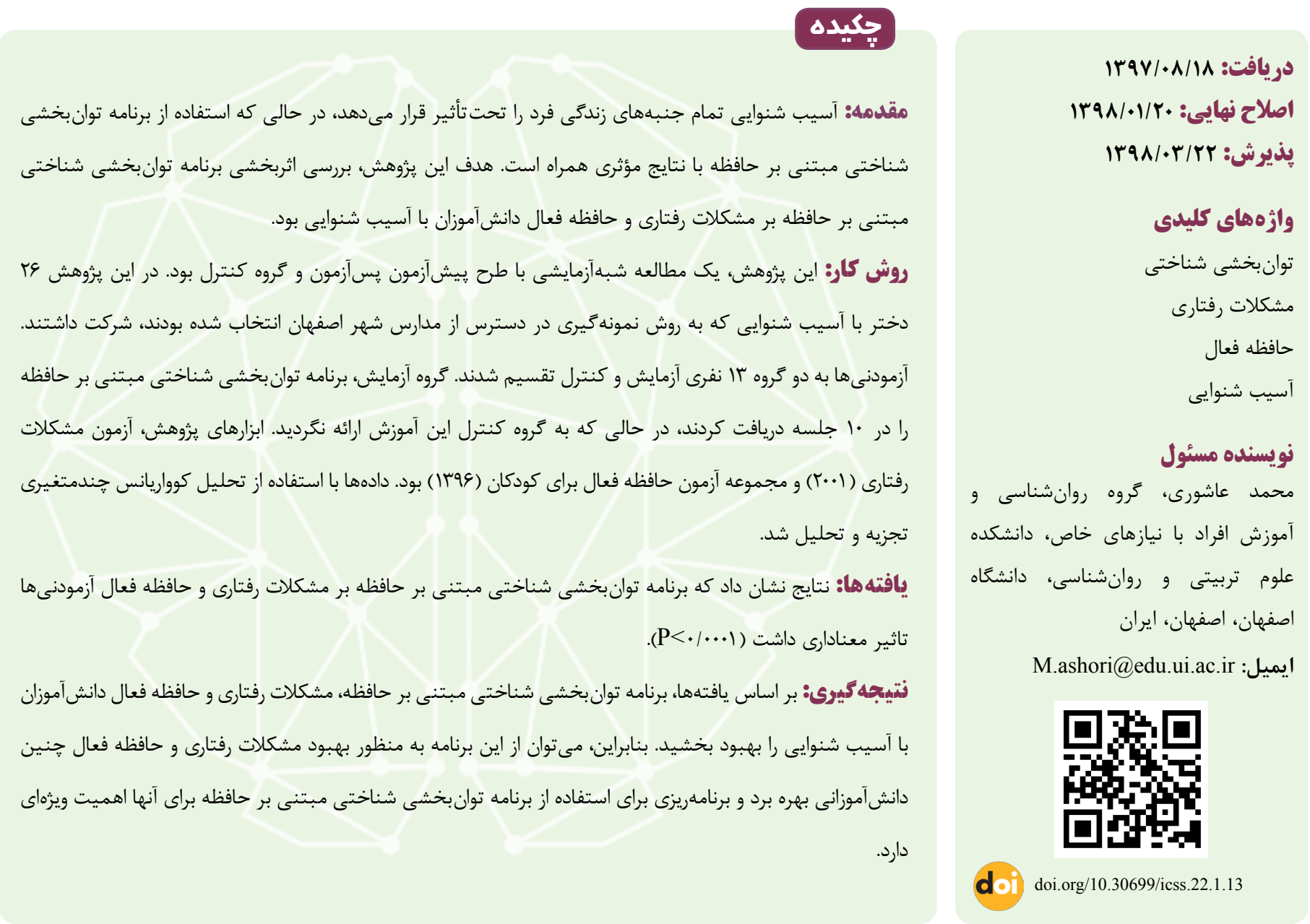

مقلدمه

افزايش مىيابد. على رغم بيشرفتهاى اخير درمانهاى يزشكى، آسيب شنوايى هنوز هم يك هالش باقى مانده است. دو تا سه كودك از هر هزار كودك، با آسيب شنوايى عميق به دنيا مى آيند (با). ناشنوايى منجر به كَشه گيرى، كاهش كيفيت زندَّى، كاهش فعاليتهاى اجتماعى و بروز مشكلات رفتارى مى گردد و در يى اين موارد به نظر مىرسد مشكلات
افراد با آسيب شنوايى يا ناشنوا يكى از زروههاى با نيازهاى ويزه هستند كه از نظر شنوايى با مشكلات عمدهاى مواجه هستند ( (1). ناشنوايى يكى از ناتوانىهايى با شيوع :ايين و رايجترين آسيب حسى عصبى است (r). در افراد ناشنوا به دليل ناتوانى در برقرارى ارتباط مطلوب و احساس بى كفايتى، احتمال ايجاد اختلالات روانشناختى و مشكلات رفتارى 
شنيدارى مربوط مىشود، زيرا آنها در برقرارى ارتباط كلامى و درى

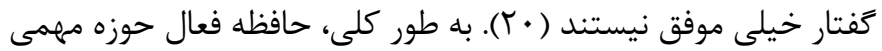

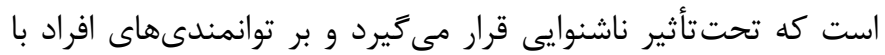
آسيب شنوايى تاثير مى گذارند. در واقع كودكان با آسيب شنوايى در دران

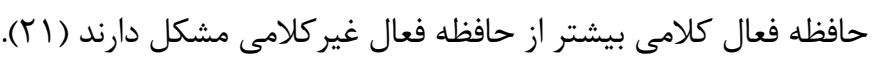

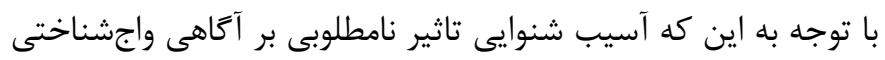

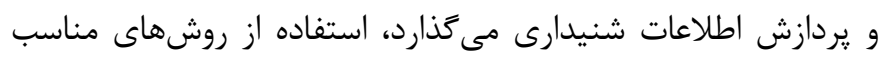

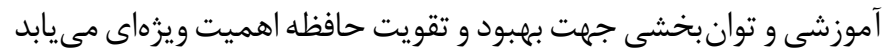
(Tr). يكى از روشهاى آموزشى موثر جهت بهبود مشكلات رفتارى و حافظه فعال كه در متون يزوهشى مختلف لحاظ شده، توانبخشى رلى شناختى مبتنى بر حافظه است (ه (1، \&). توانبخشى شناختى به عنوان يك روش آموزشى و درمانى براى مشكلات شناختى است كه كاركردهاى آسيبديده را از طريق راهبردهاى آموزشى، تكرار و تمرين ترميم مى كند

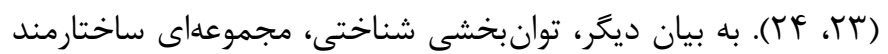

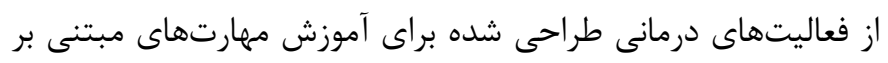

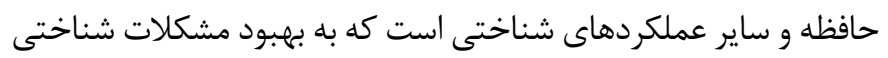

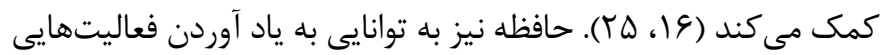

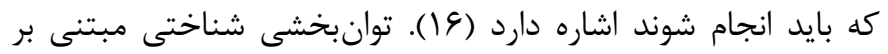
حافظه به فرايندهاى شناختى به منظور يادآورى رويدادهايى كَفته

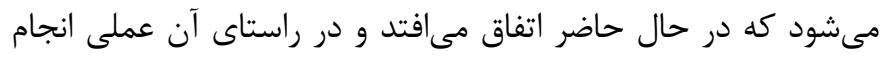
خواهد شد (צ)). در واقع، توانبخشى شناختى مىتواند هم به صورت مستقيم بر حافظه فعال تاثير بحذارد و هم به صورت غيرمستقيم از طريق

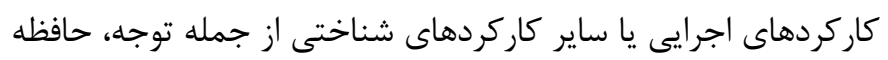

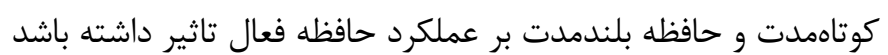
(TV)

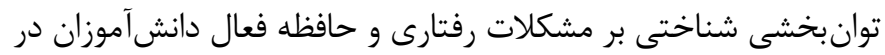
سنين مختلف و حوزههاى مختلف معطوف شده است. در اين راستا،

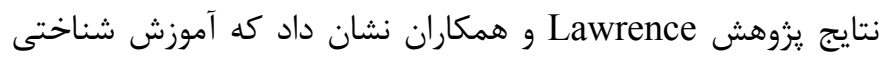
به صورت شفاهى شنيدارى سبب بهبود يادگيرى، توجه و حافظه افراد

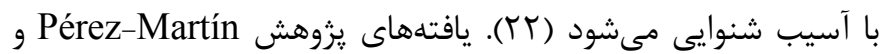

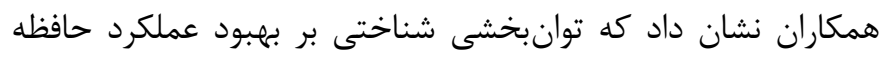

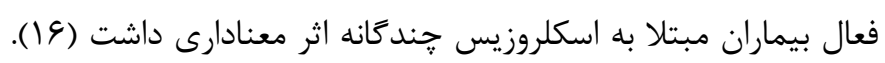

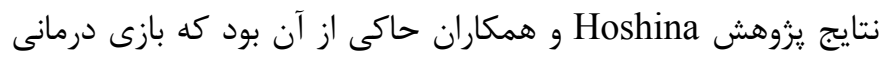
ديجيتالى باعث افزايش توجه و مهارتهاى ارتباطى و اجتماعى كودكان

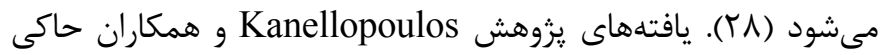
از آن بود كه توانبخشى شناختى بر مشكلات رفتارى و حافظه فعال

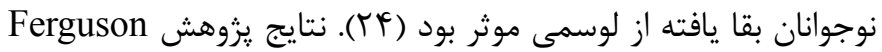

مربوط به حافظه، به ويزه حافظه فعال (Working Memory) در اين كودكان افزايش يابد (†). در واقع، مشكلات رفتارى كودكان به ويزه در

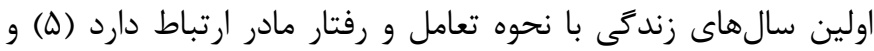

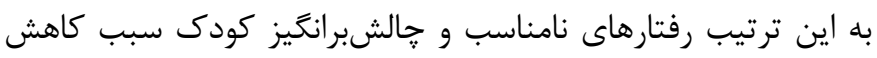

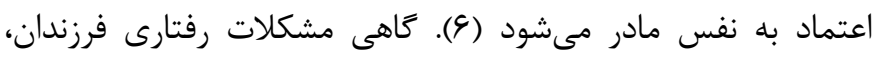

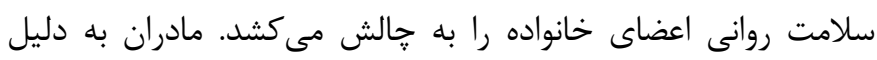

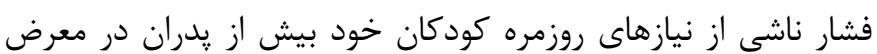
آسيبهاى وابسته به سلامتى قرار مى گيرند (V)، جرا كه مادر به عنوان عضو اصلى خانواده، كاركردها و مسئوليتهاى مختلفى را در رابطه با فيا

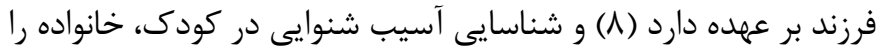
با بحران روبرو مى كند (9). امروزه بهبود شرايط زندكى افراد با نيازهاى

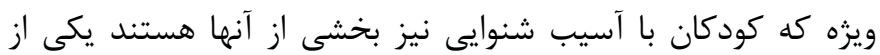
هدفهاى عمده توانبخشى محسوب مىشود (• (1).

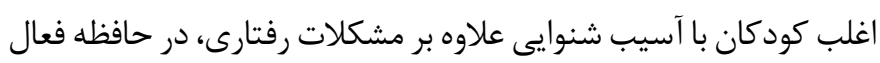

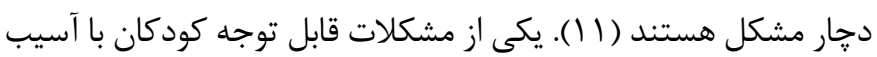

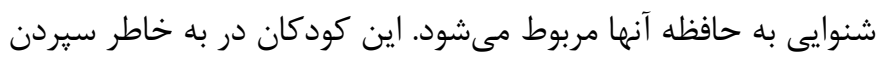
و يادآورى اطلاعات يا انجام عملى كه بايد انجام دهند مشكل دارند.

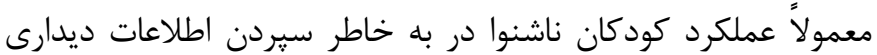
مشكل زيادى ندارند و بيشتر مشكلات آنها به اطلاعات شنيدارى مربوط

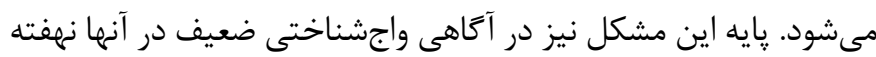

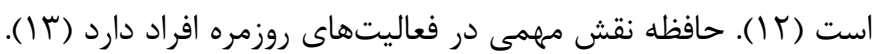

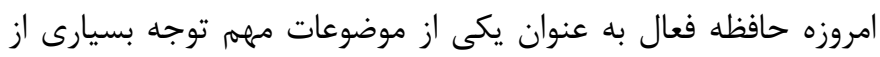

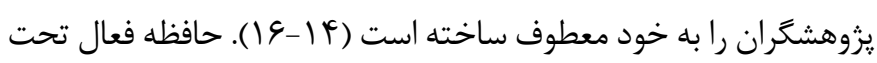
عنوان سيستم حافظهاى توصيف مىشود كه به طور موقت انواع اطلاعات را نخَهدارى و دستكارى مى كند (V) ). حافظه فعال همان توانايى نكَهدارى اطلاعات در ذهن در حين انجام تكاليف پييجيده است و توانايى نظارت بر عملكرد و ارزيابى بردازشهاى شناختى را در بر مى گيرد. حافظه فعال

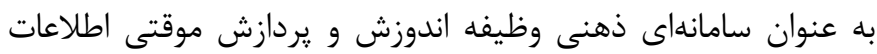
براى انجام تكاليف يِيجيده شناختى را به عهده دارد (1) (1). به بيان ديكر،

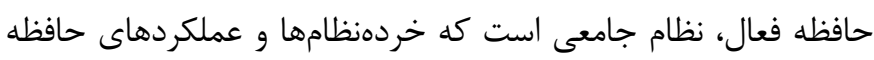
كوتامدت و بلندمدت را به همم متصل مىسازد و به جهار بخش مجرى

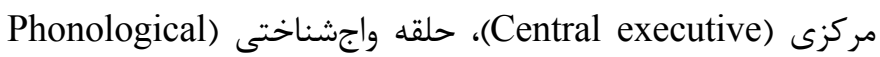

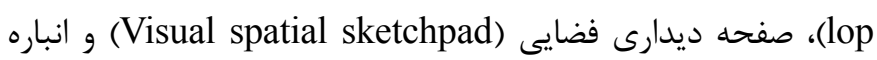
رويدادى (Episodic buffer) تقسيم مىشود (19). كود كان و نوجوانان ناشنوا نسبت به همسالان عادى خود مشكلات شناختى بيشترى را تجربه مى كنند و اين مشكلات تاثير نامطلوبى بر عملكرد تحصيلى آنها

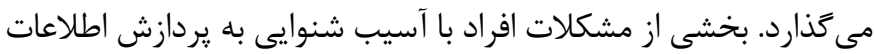


راهبردهاى شناختى يا توان-بخشى شناختى يرداختهاند كه كلى هستند

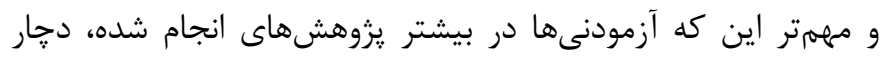

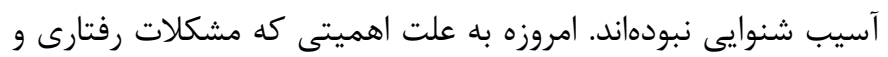

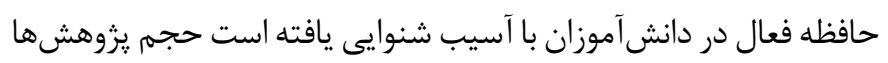

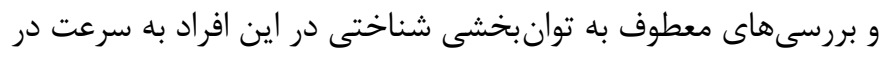

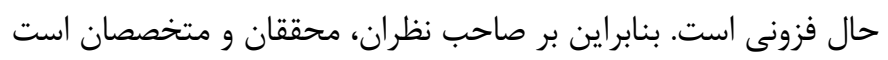

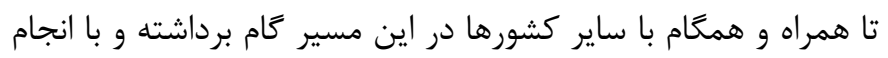
يزوهشهاى منطبق بر ويزگىهاى دانشآموزان با آسيب شنوايى، با توانبخشى شناختى مبتنى بر حافظه به بهبود مشكلات رفتارى و حافظه فعال اين قشر از افراد جامعه همت كمارند. بنابراين، هدف اصلى اين

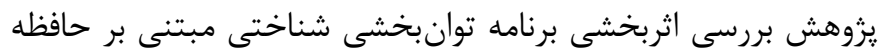

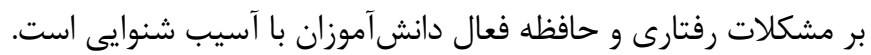

\section{روش كار}

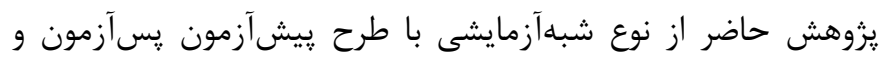

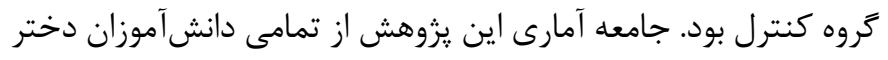

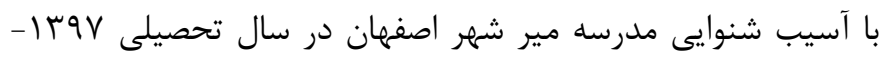

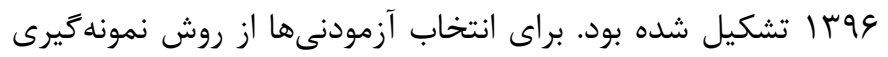

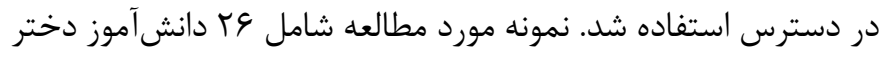

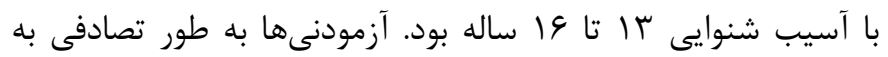

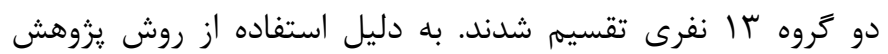

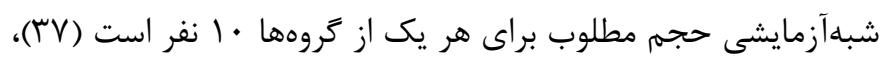

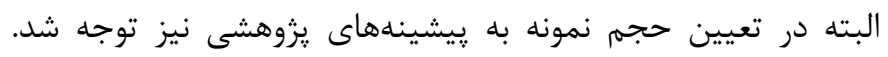

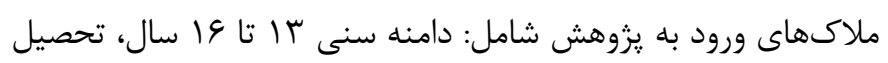

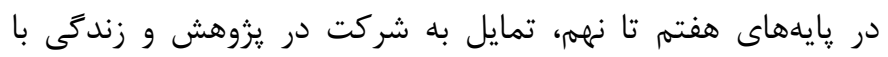
يدر و مادر بود. ملاكهاى خروج از مطالعه نيز شامل: غيبت بيشتر از دو جلسه در جلسات آموزشى، مصرف داروهاى محرى يا غيرمحرى،

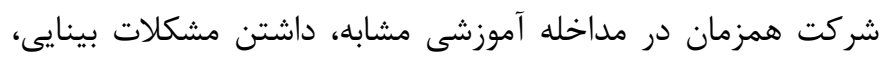
جسمى حركتى يا اختلالهايى مانند كمتوانى ذهنى و طلاق يا جدايى

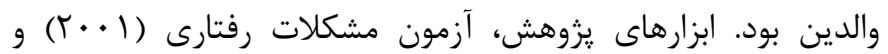

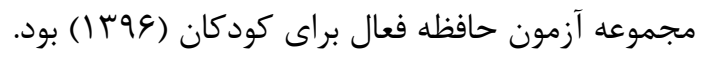

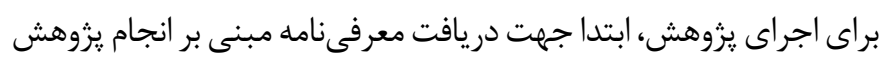

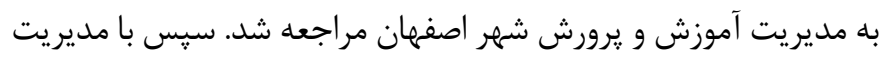

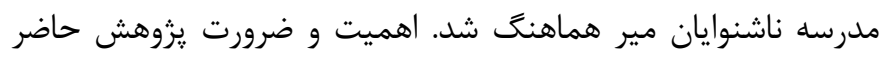
براى مدير مدرسه و مادران دانشآموزان ناشنوا بيان شد. از تمامى والدين رضايتنامه كتبى مبنى بر شركت فرزندانشان در يزوهش اخذ و به آنها

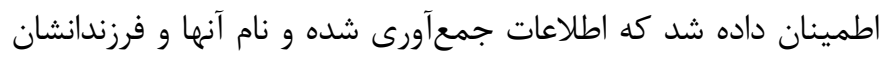

و نشان داد كه آموزش و توانبخشى شنيدارى سبب بهبود

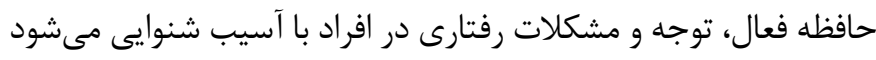

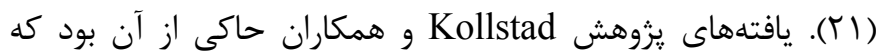

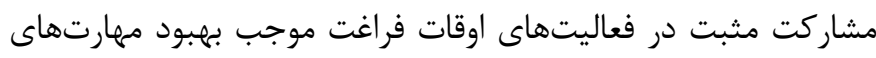
عصبروانشناختى از جمله حافظه، توجه و كاركردهاى اجرايى افراد

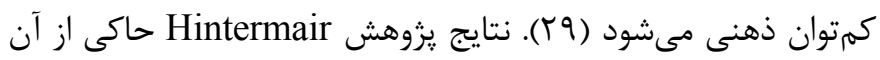

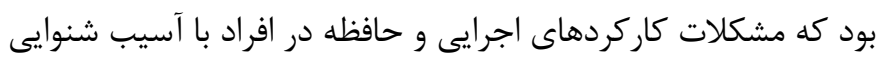
بيشتر از افراد عادى است و از طريق توانبخشى شناختى مىتوان

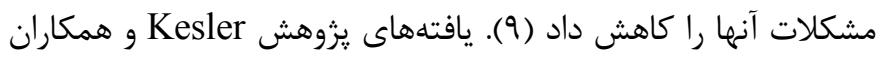
حاكى از اثربخشى برنامه بازتوانى شناختى آنلاين بر مهارتهاى كاركرد

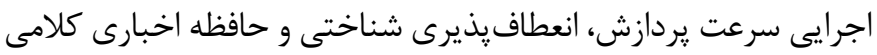

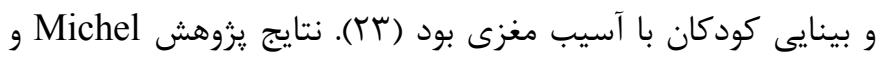

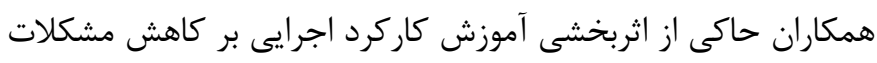

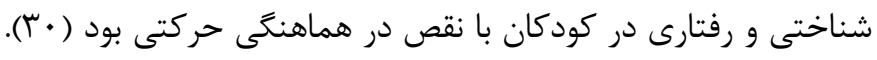

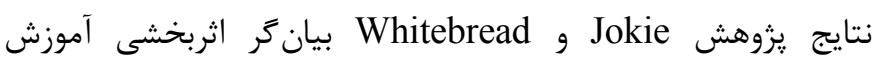
مهارتهاى خودَردان و فراشناخت بر عملكرد رفتارى و حركتى كودكان

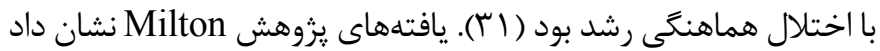

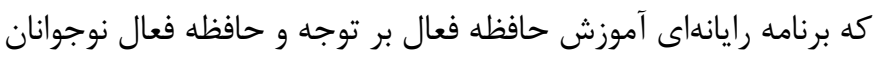
داراى اختلال كمتوجهى بيشفعالى و اختلال يادكيرى موثر است (Tr).

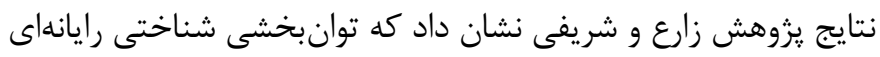

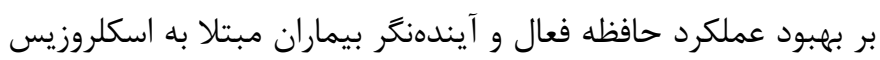

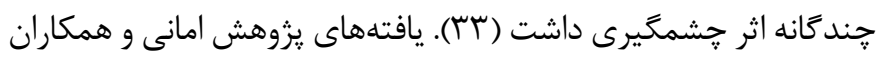

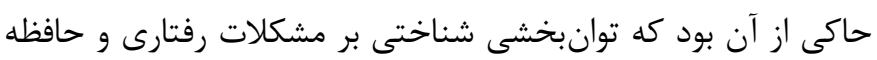

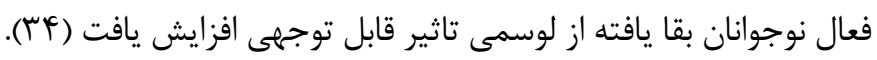

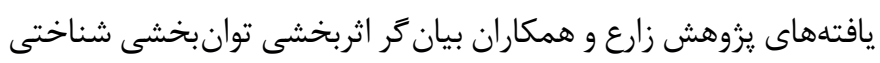

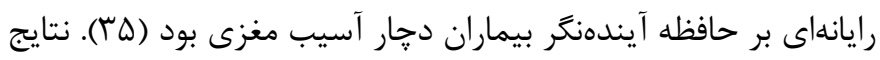
يزوهش ارجمندنيا و همكاران نشان داد كه مداخله شناختى بر عملكرد

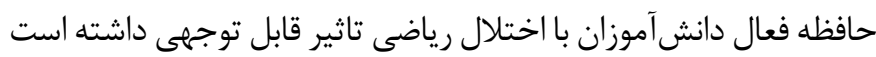
(19). يافتههاى يزوهش قمرى و همكاران بيان

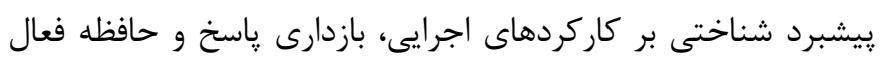

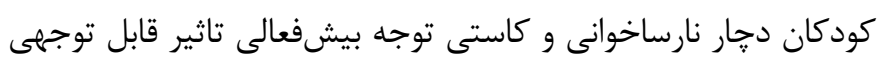

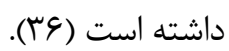
بر اساس ييشينهاى يزوهشى احتمال مىرود كه توانبخشى شناختى

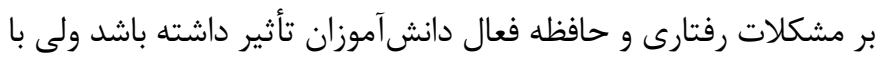

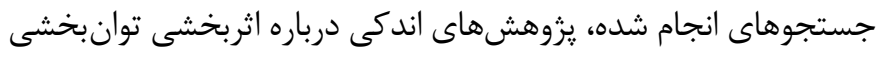
شناختى مبتنى بر حافظه بر مشكلات رفتارى و حافظه فعال دانشآموزان

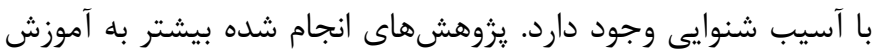


مقياس مشكلات رفتارى درونىسازى شده از سه عامل نخست و همجنين مقياس مشكلات برونسازى شده از دو عامل آخر را تشكيل مىشود. عاملهاى باقيمانده نيز تحت عنوان مشكلات ديخًر طبقهبندى مىشود. مقياس مشكلات كلى نيز شامل همه گَويه ها به جز گويه هاى

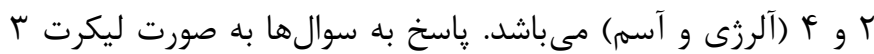
كزينهاى از • تا ب مى باشد. بدين ترتيب كه نمره صفر به مواردى تعلق مى گيرد كه هر ₹ز در رفتار كودى وجود ندارد؛ نمره يك به مواردى داده مىشود كه كاهى اوقات در كودى مشاهده مى شود و نمره دو نيز به مواردى داده مىشود كه بيشتر مواقع يا هميشه در رفتار كودك وجود دارد. يايايى آزمون بازآزمون مقياسها بين س9/ • تا ا به دست آمده است. ضرايب كلى اعتبار با استفاده از آلفاى كرنباخ VY/ • و با استفاده از اعتبار بازآزمايى 94/ • زَزارش شده است. روايى محتوايى، روايى ملاكى و روايى سازه نيز مطلوب گزارش شده است ( • (ا). يزدخواستى و عريضى (• وجا) ضريب اعتبار آلفاى كرونباخ را براى اين فهرست مشكلات رفتارى در سه فرم والدين، معلم و كودك به ترتيب • 9/ •،

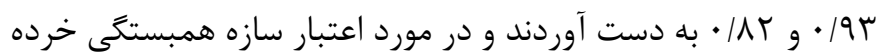
مقياس هاى بخش مشكلات رفتارى هيجانى با نمره كلى اين بخش در

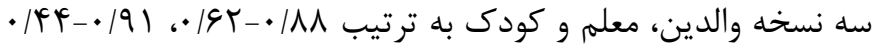

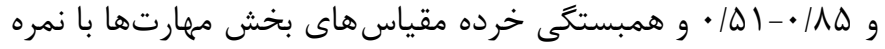
كلى اين بخش در سه نسخه والدين، معلم و كودك به ترتيب 1AT|• F حاضر، ضرايب آلفاى كرنباخ مقياس مشكلات رفتارى درونى سازى، برونسازى شده و مقياس مشكلات كلى به ترتيب AV • •

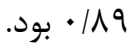

children (WMTB-C)) مجموعه آزمون حافظه فعال براى كودكان Pickering (Working memory test battery for

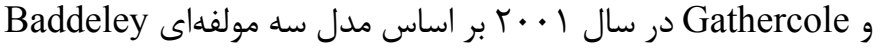
و Hitch (حلقه واجشناختى، صفحه ديدارى فضايى و مجرى مركزى)، به منظور سنجش حافظه فعال (شناخت و ييشرفت كلى) كودكان و نوجوانان ه تا ها ساله طراحى كردهاند (r (F)، و ارجمندنيا آن را در سال

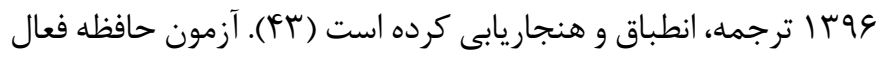

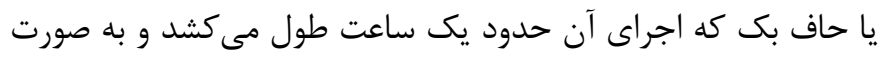

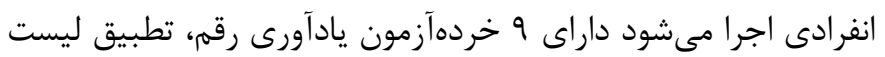

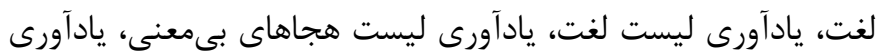

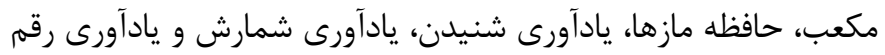
رو به عقب است. اين آزمون، عملكرد مولفه حلقه واجشناختى را با مجموع

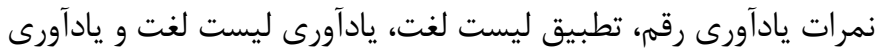

به صورت محرمانه باقى خواهد ماند. شركت در يزوهش نياز به هيج گونه هزينهاى نداشت، هيج ضرر و زيانى شركت كنندكان را تهديد نمى كرد، اجازه ترك جلسات آموزشى و عدم ادامه همكارى با يزوهشكر به آنها

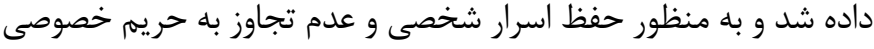
افراد، نتايج به شكل شاخصهاى كلى كزارش و در اختيار روانشناسان

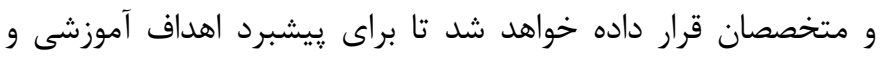

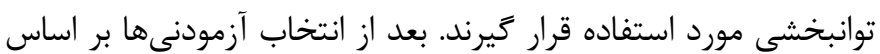
ملاكهاى ورود و خروج يزوهش و جايكزينى در تروه آزمايش و كنترل، فهرست مشكلات رفتارى كودى و مجموعه آزمون حافظه فعال براى هر دانشآموز به عنوان بيش آزمون تكميل شد. آزمودنىها كروه آزمايش بعد از اجراى يِيشآزمون در برنامه توانبخشى شناختى مبتنى بر حافظه شركت كردند. اين برنامه بر اساس يروتكل توانبخشى شناختى مبتنى

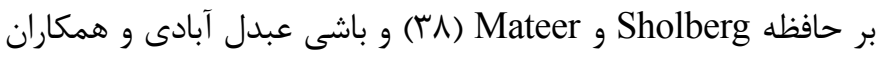
(9) تنظيم شده كه مداخلهاى شناختى و عصبشناختى است و بر آنا توانايىهاى شناختى مبتنى بر حافظه و اجزاى آن تمركز دارد. در جلسات

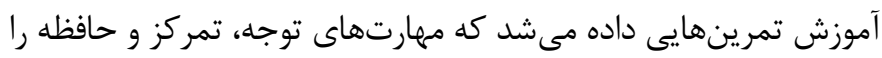

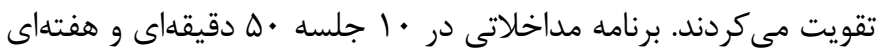
دو جلسه اجرا شد. سطح دشوارى تكاليف به كونهاى بود كه با پِيشرفت مهارت آزمودنىها، تكاليف هم به طور ييشرونده دشوارتر مىشدند. هدف و محتواى برنامه توانبخشى شناختى مبتنى بر حافظه به تفكيك جلسات در جدول ا آمده است. تمامى آزمودنى ها در قبل و بعد از مداخله با استفاده از فهرست مشكلات رفتارى كودى و آزمون حافظه فعال براى كودكان مورد ارزيابى قرار

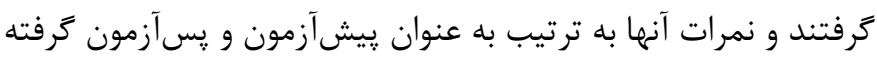

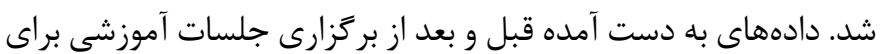

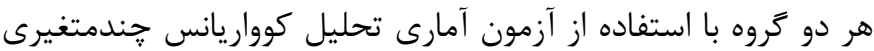
مورد تجزيه و تحليل قرار كرفت. جهت تحليل دادهها از نرمافزار آمارى SPSS-23

فهرست مشكلات رفتارى كودى ) behavior checklist (CBCL))

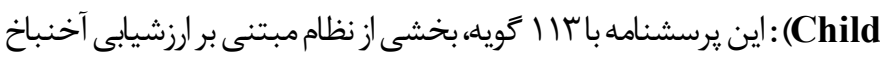
(Achenbach system of empirically based assessment (ASEBA)) است كه انواع مشكلات رفتارى كودكان و نوجوانان 11 14 ساله را از ديدكاه والدين، معلم يا كودك در شش ماه كذشته در ^ عامل اضطراب|

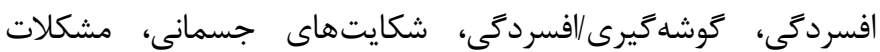
اجتماعى، مشكلات تفكر، مشكلات توجه، ناديده گرفتن قواعد و رفتار يرخاشكرانه ارزيابى مى كند. در اين يزوهش از فرم والدين استفاده شد. فهرست مشكلات رفتارى كودى از سه مقياس تشكيل شده است: 


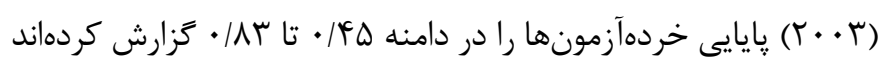

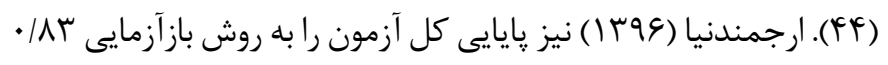

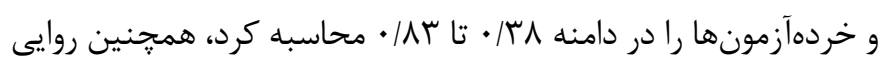

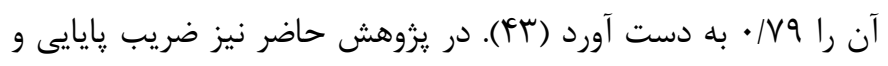

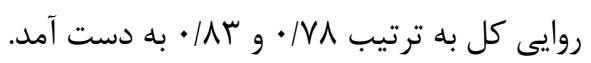

ليست هجاهاى بىمعنى؛ عملكرد مولفه صفحه ديدارى فضايى را با مجموع

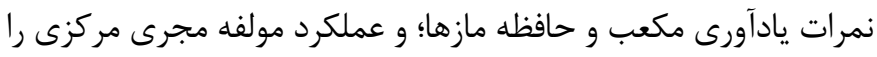

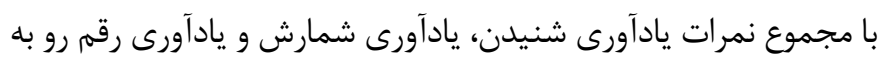

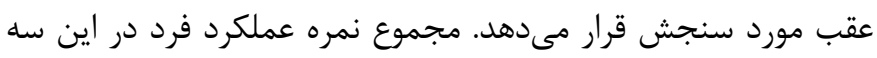

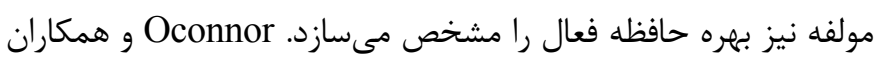

جدول 1. هدف و محتواى برنامه توانبخى شناختى مبتنى بر حافظه

محتوا

هدف

حلسات

توضيح درباره ساختار جلسات، برنامهريزى، هدف كذارى، روشها و تمرينهاى شناختى آموزش با كمك ياديارها، تمرين حافظه ديدارى تصويرى مانند بازى يادآورى جهره آموزش پسخبا، كوش بهزنگى نسبت به محركهاى شنيدارى و حفظ توجه نسبت به محركهاى ديدارى

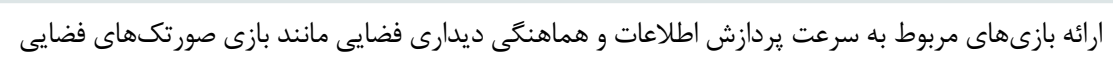

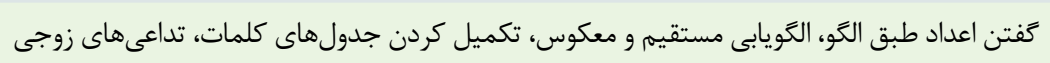
تغيير توجه در حافظه رويدادى، توجه انتخابى و يردازش توجه، سازماندهى كلامى، كسترش معنايى ياديارها، تصويرسازى زمانى و مكانى با يادآورى تجربههاى كذشته اخير و فورى

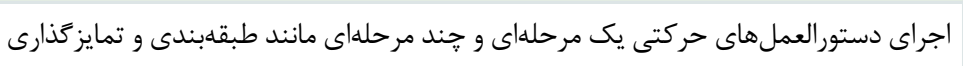
تصويرسازى و حل مساله بهصورت ذهنى، برنامهريزى، حذف تدريجى نشانههاى حافظهاى مرورى بر محتواى جلسات و آماده كردن آزمودنى براى خروج از برنامه توانبخشى شناختى مبتنى بر حافظه

ا برقرارى ارتباط و معرفى برنامه

r م إفويت حافظه ديدارى تصويرى

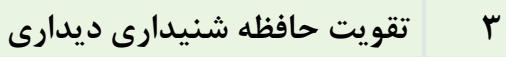

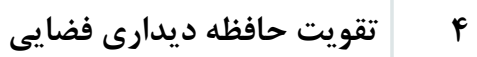
ه تقويت حافظه عددى و تداعى كلمات q عقويت حافظه رويدادى و بسط شناختى

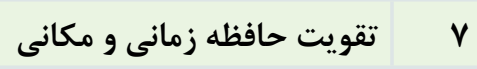
1 1 9 ا خروج از برنامه و جمعبندى

يافته ها

كوواريانس جندمتغيرى ديخر استفاده شد. براى تعيين تاثير برنامه توانبخشى شناختى مبتنى بر حافظه بر مشكلات رفتارى درونى سازى شده، برونسازى شده و مشكلات رفتارى كلى، آزمون باكس فرض همخنى واريانس_كوواريانس را تاييد كرد كه برابر با

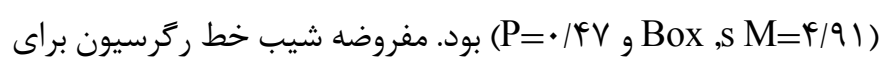
متغيرها و خطى بودن رابطه متغيرها برقرار بود. آزمون كرويت بارتلت حاكى از وجود همبستخى كافى بين متغيرهاى وابسته بود ( ( + (P= (P). نتايج آزمون لون نيز برقرارى فرض همخنى واريانسها در همه متغيرها

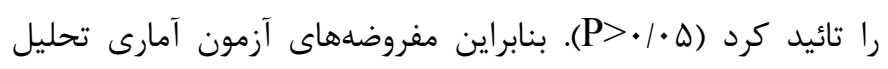
كوواريانس جندمتغيرى برقرار بود. به اين منظور، متغيرهاى مشكلات رفتارى درونى سازى شده، برونسازى شده و مشكلات رفتارى در گروه آزمايش و كنترل در ييشفرض آمارى بزرگترين ريشه روى روى مورد

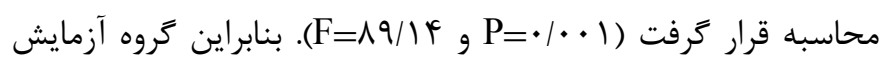
و كنترل حداقل در يكى از متغيرها تفاوت معنادارى دارند. به منظور يىبردن به اين تفاوت، از آزمون آمارى تحليل كوواريانس جند متند متغيرى استفاده شد كه نتايج هر يك در جدول ب آمده است.
ميانگين و انحراف استاندارد سن آزمودنىها در زروه آزمايش

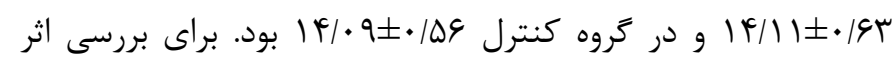

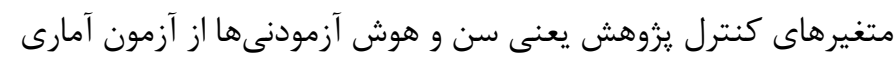

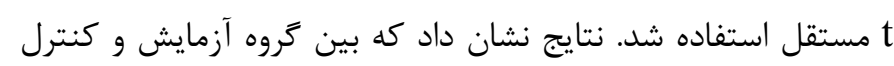
از نظر سن و هوش تفاوت معنادارى وجود ندارد (ه • • P> (P). ميانخين و انحراف معيار متغيرهاى مشكلات رفتارى (مشكلات رفتارى درونى هازى شده، برونسازى شده و مشكلات كلى) و نيمرخ حافظه فعال (مجرى مركزى، صفحه ديدارى فضايى، حلقه واجشناختى) در دو گروه آزمايش و كنترل در موقعيت ييشآزمون و يسآزمون در جدول بارائه شده است.

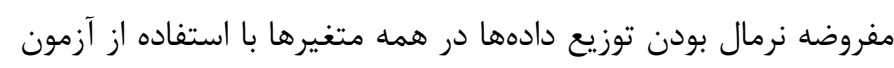

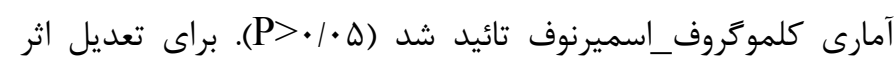
״يش آزمون و به علت وجود يك متغير مستقل (برنامه توانبخشى شناختى مبتنى بر حافظه) و سه متغير وابسته مشكلات رفتارى درونى سازى شده، برونسازى شده و مشكلات رفتارى كلى از يك آزمون آمارى تحليل كوواريانس جندمتغيرى و همجنين سه متغير وابسته مجرى مركزى مرى صفحه ديدارى_فضايى، حلقه واجشناختى از يك آزمون آمارى تحليل 
را تائيد كرد (ه>/P> Pنابراين مفروضههاى آزمون آمارى تحليل كوواريانس קندمتغيرى برقرار بود. به اين منظور، متغيرهاى مجرى مركزى، صفحه ديدارى_فضايى، حلقه واجشناختى در گروه آزمايش و

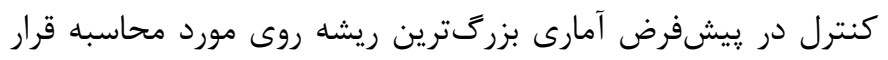

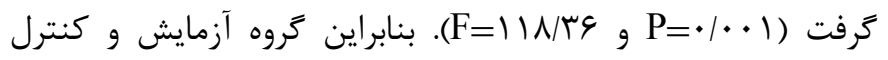

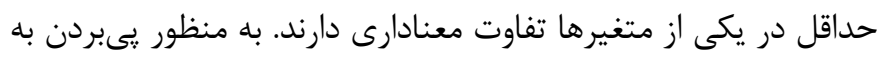

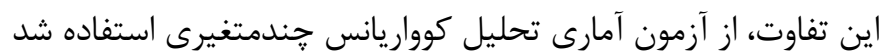
كه نتايج هر يك در جدول با آمده است. با توجه به نتايج جدول أ، كروه اثر معنادارى بر نمرات مجرى مركزى

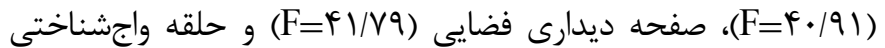

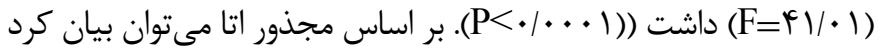
به ترتيب بَع، •و و بو درصد تغييرات هر يك از متغيرهاى مجرى مركزى، صفحه ديدارى_فضايى و حلقه واجشناختى به علت اثر مداخله است.
با توجه به نتايج جدول س، گروه اثر معنادارى بر نمرات يسآزمون

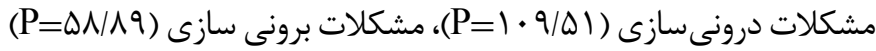

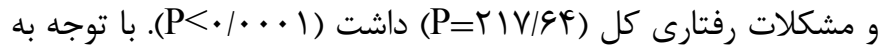
مجذور اتا مىتوان بيان كرد به ترتيب س هو، و4و V د درصد تغييرات هر يك از متغيرهاى مشكلات درونىسازى، برونى سازى و مشكلات رفتارى

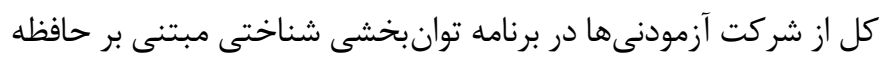

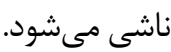
براى تعيين اثربخشى برنامه مداخلاتى بر نيمرخ حافظه فعال آزمون باكس فرض همخنى واريانس_كوواريانس را تاييد كرد كه برابر با تراني (P=• بود. مفروضه شيب خط ركرسيون براى متغيرها و خطى بودن رابطه متغيرها برقرار بود. آزمون كرويت بارتلت

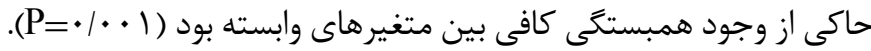

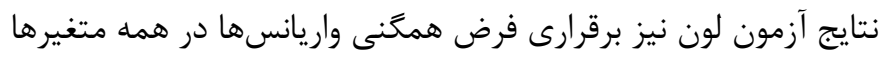

جدول r. ميانخين و انحراف معيار مشكلات رفتارى و حافظه فعال در تروه آزمايش و كنترل

\begin{tabular}{|c|c|c|c|c|c|c|}
\hline \multicolumn{2}{|c|}{ گروه كنترل } & \multicolumn{2}{|c|}{ گَروه آزمايش } & \multirow{2}{*}{ موقعيت } & \multirow{2}{*}{\multicolumn{2}{|c|}{ متغير ها }} \\
\hline انحراف معيار & ميانگين & انحراف معيار & ميانگين & & & \\
\hline$\cdot / 49$ & $1 \cdot / 11$ & $\cdot / r V$ & $1 \cdot / r T$ & پِيش آزمون & \multirow{2}{*}{ درونى سازى } & \multirow{6}{*}{ مشكلات رفتارى } \\
\hline .119 & $9 / 11$ & $\cdot /$ TF & $9 / 1 \pi$ & يس آزمون & & \\
\hline$\cdot|q|$ & $19 / 1 \Delta$ & $\cdot / 4 q$ & $19 / 1 \Delta$ & ييش آزمون & \multirow{2}{*}{ برونى سازى } & \\
\hline$\cdot / r v$ & $|9| \cdot V$ & $\cdot|r|$ & $\mid r / 1 \cdot$ & يس آزمون & & \\
\hline $1 / \cdot 1$ & $r \Delta / 9 V$ & $1 / \cdot r$ & $r \omega / v e$ & 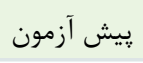 & \multirow{2}{*}{ كلى } & \\
\hline $1 / 11$ & $r \Delta / 11$ & $1 / \cdot F$ & $r V / T \cdot$ & يس آزمون & & \\
\hline $1 / \pi$ & $\Delta \Lambda / 1$ & $1 / 14$ & $\Delta q / \vee \Delta$ & 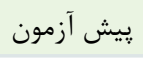 & \multirow{2}{*}{ مجرى مركزى } & \multirow{6}{*}{ حافظه فعال } \\
\hline$|/ 4|$ & $\Delta N / \cdot r$ & I/TF & $9 \Delta / 10$ & يس آزمون & & \\
\hline $1 / 4 T$ & $\Delta r / 19$ & $1 / T \Delta$ & $\Delta r / \varphi \varphi$ & 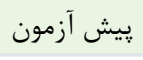 & \multirow{2}{*}{ صفحه ديدارى_فضايى } & \\
\hline $1 / \mu$ & $\Delta r / 9 V$ & $1 / 4 \Delta$ & $q \cdot 1 \Delta V$ & يس آزمون & & \\
\hline $1 / 49$ & $V F / I f$ & $1 / 94$ & $V T / T V$ & 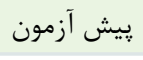 & \multirow{2}{*}{ حلقه واجشناختى } & \\
\hline $1 / \Gamma \wedge$ & $V r / q r$ & $1 / \Delta F$ & $V q / 4 r$ & آزمون & & \\
\hline
\end{tabular}

جدول r. نتايج تفكيكى مانكووا براى مشكلات رفتارى درونىسازى، برونسازى و مشكلات رفتارى

\begin{tabular}{|c|c|c|c|c|c|c|c|}
\hline مجذور اتا & $\mathbf{P}$ & $\mathbf{F}$ & مجيانگين & درجه & مجذموع مجذورت & منابع تغيير & متغير هاى وابسته \\
\hline . & $\cdot|\cdots|$ & $\Lambda \Delta / \Delta \Delta$ & $1.9 / 01$ & 1 & $1.9 / 01$ & 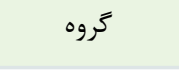 & مشكلات درونى سازى \\
\hline .199 & $\cdot|\cdots|$ & FT/QA & $\Delta \wedge / \wedge q$ & 1 & $\Delta \Lambda / \wedge q$ & 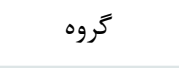 & مشكلات برونسازى \\
\hline $.19 \mathrm{~V}$ & $\cdot|\cdots|$ & TIV/GY & rqG/TY & 1 & TQG/TF & كروه & مشكلات رفتارى كل \\
\hline
\end{tabular}


جدول \&. نتايج تفكيكى مانكووا براى مجرى مركزى، صفحه ديدارى_فضايى، حلقه واجشناختى

\begin{tabular}{|c|c|c|c|c|c|c|c|}
\hline مجذور اتا & $\mathbf{P}$ & $\mathbf{F}$ & مجذذوراتين & درجادي & مجذمورع & منابع تغيير & متغير هاى وابسته \\
\hline . &.$|\cdots|$ & $4 \cdot / 91$ & $r Q / \wedge V$ & 1 & $r q / \Lambda V$ & كروه & مجرى مركزى \\
\hline .19 &.$\cdots 1$ & $\varphi 1 / v q$ & $r \Delta / q)$ & 1 & $r \Delta / q)$ & كروه & صفحه ديدارى_فضايى \\
\hline .194 &. $\mid \cdots 1$ & $\mid+1 / \cdot 1$ & $r F / A \varphi$ & 1 & $r F / \Lambda q$ & 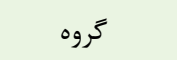 & حلقه واجشناختى \\
\hline
\end{tabular}

شنيدارى باشد با مشكل مواجه مىشوند. روش ابراز اين مشكلات نمود رفتارى دارد و به صورت ضعف در مهارتهاى رفتارى برجسته مىشود (I (I). در حالى كه توانبخشى شناختى مبتنى بر حافظه يكى از روشهاى آموزشى جهت بهبود مشكلات رفتارى كودكان است (ها، 91). برنامه توانبخشى شناختى مىتواند كاركردهاى آسيبديده كودى را از طريق راهبردهاى آموزشى، تكرار و تمرين ترميه كند (سT). دانشآموزان با آسيب شنوايى در مهارتهاى رفتارى با مشكل مواجه هستند و در مقايسه با كود كان عادى به خدمات آموزشى و توانبخشى ويزهاى نياز دارند (\&\&). افراد با آسيب شنوايى نسبت به همسالان عادى خود مشكلات شناختى بيشترى دارند و اين مشكلات تاثير نامطلوبى بر رفتارهاى آنها مى گذارد (·ץ). در واقع توانبخشى شناختى، مجموعهاى ساختارمند از اقدامات آموزشى مبتنى بر مهارتهاى حافظه و عملكردهاى شناختى است كه بر بهبود مشكلات توجهى و رفتارى تاكيد دارد و توانايى به ياد آوردن فعاليتهاى روزمره را تقويت مى كند (1) (1). برنامه توانبخشى شناختى مبتنى بر حافظه سبب مىشود تا كودكان آكاهى بيشترى نسبت به رفتارها و مشكلات خود ييدا كنند و راههاى مناسبترى براى رفع جنين مشكلاتى بيابند (צr). از آن جايى آن آن كه برنامه توانبخشى مذكور شامل فعاليتهاى جذاب و مورد علاقه كودكان است و اين فعاليتها از طريق بازى ارائه مىشوند كودكان با آسيب شنوايى به طور فعال و خودانخيخته در آن مشاركت مى كنند و به نظر مىرسد تاثير قابل توجهى بر كاهش مشكلات رفتارى آنها داشته باشد. پس دور از انتظار نيست كه آموزش برنامه توانبخشى شناختى

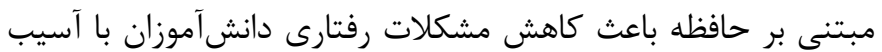
شنوايى شود. دومين يافته اين يثروش بيان گر آن بود كه آموزش برنامه توانبخشى

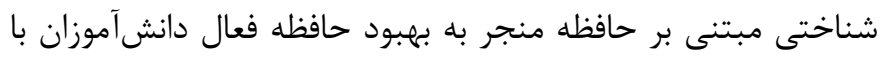

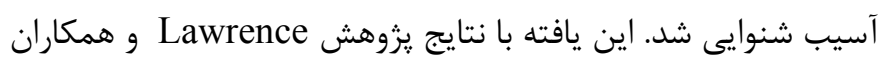
مبنى بر اثربخشى آموزش شناختى بر بهبود يادگيرى، توجه و حافظه
يروهش حاضر با هدف بررسى اثربخشى برنامه توانبخشى شناختى

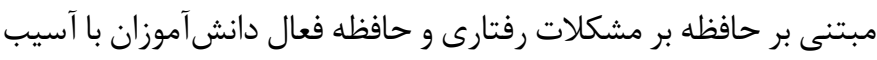
شنوايى انجام شد. نخستين يافته يزوهش حاضر حاكى از آن بود كه اين آموزش منجر به بهببود مشكلات رفتارى دانشآموزان با آسيب شنوايى شد. اين يافته با نتايج يثوهش Hoshina و همكاران مبنى بر اثربخشى بازى درمانى ديجيتالى بر توجه كودكان (Kᄉ)؛ Kanellopoulos و همكاران در خصوص اثربخشى توانبخشى شناختى بر مشكلات رفتارى

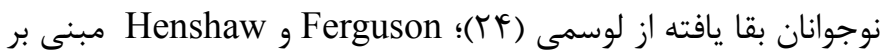
اثربخشى آموزش و توانبخشى شنيدارى بر بهبود حافظه فعال، توجه و مشكلات رفتارى در افراد با آسيب شنوايى (II)؛ Michel و همكاران مبنى بر اثربخشى آموزش كاركرد اجرايى بر كاهش مشكلات شناختى و رفتارى در كودكان با نقص در هماهنگگى حركتى (•")؛ Jokie و دhitebread فراشناخت بر عملكرد رفتارى و حركتى كودكان با اختلال هماهنگى رشد ( آl) بود همسو است. همجنين با يافتههاى امانى و همكاران مبنى بر اثربخشى توانبخشى شناختى بر مشكلات رفتارى نوجوانان بقا يافته از لوسمى (TK) و قمرى و همكاران در خصوص تاثير مثبت و معنادار نرمافزار پيشبرد شناختى بر كاركردهاى اجرايى و بازدارى پاسخ كودكان دجار نارساخوانى و كاستى توجه بيشفعالى (צץ) همخوانى دارد. در تبيين اين يافته كه برنامه توانبخشى شناختى مبتنى بر حافظه سبب بهبود مشكلات رفتارى دانشآموزان با آسيب شنوايى شد، مىتوان كفت كود كان با نيازهاى ويزه در ابراز هيجانهاى خود به نحو مطلوبى عمل نمى كنند (هأ). يكى از عمدهترين مشكلات كودكان ناشنوا، مشكل در برقرارى ارتباط است و همين امر حساسيت و زودرنجى آنها را تشديد مى كند و به دنبال آن مشكلات رفتارى اين كودكان بيشتر مىشود (؟). از سوى ديكر، مشكلات رفتارى كودكان با آسيب شنوايى با مشكلات

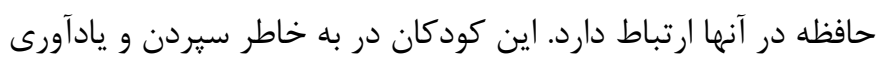
اطلاعات يا انجام عملى كه بايد انجام دهند، به ويزه اخر اطلاعات مربوطه 
به طور خود به خود افزايش مى يابد ولى دانشآموزان با آسيب شنوايى كمتر در فعاليتهاى روزمره شركت مى كنند و توان ذهنى آنها به حالش

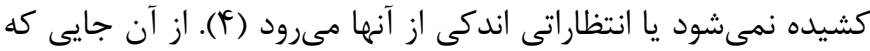

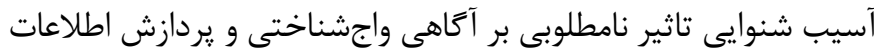

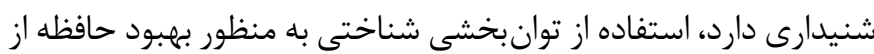

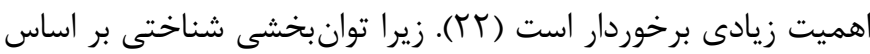

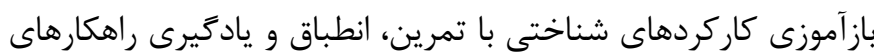
مقابله، استوار مىباشد (FV). علاوه بر اين، دانش آموزان با آسيب شنوايى آنسي به دليل وجود آسيبهاى جدى در فرايندهاى شناختى به ويزه در حافظه با مشكلات عمدهاى مواجه هستند. بنابراين يكى از اهداف اصلى آموزش اين كودكان، توجه به مشكلات شناختى آنها است (ז). از سوى ديكر، برنامه توانبخشى شناختى مبتنى بر حافظه به فرايندهاى شناختى به

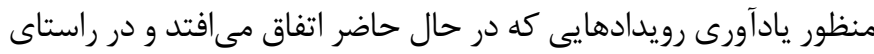

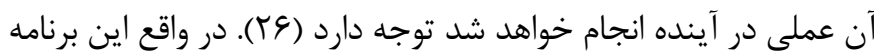

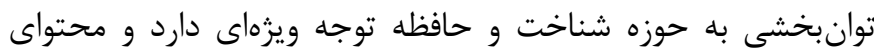
جلسات آن بر همين اساس تدوين شده است. بنابراين، دور از انتظار

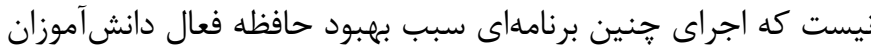

$$
\text { با آسيب شنوايى شود. }
$$

به طور كلى، پايههاى نظرى برنامه توانبخشى شناختى مبتنى بر حافظه بر اساس يزوهشهاى باركلى است. از نظر باركلى جنانجه كاركردهاى

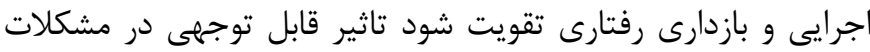

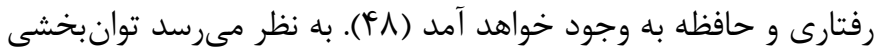
شناختى مبتنى بر حافظه جهت بهبود توجه و حافظه فعال كودكان با

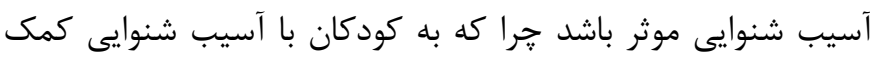
مى كند كه در برخورد با مشكلات تحصيلى و رفتارى از راهبردهاى باى برائ مناسب براى حل مشكل استفاده كنند و بتوانند مشكلات خود را حل كنند (r). علاوه بر اين، بخش عمدهاى از مشكلات دانشآموزان با آسيب

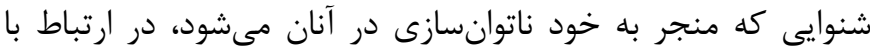
عملكرد و رفتار در زندگى شخصى و اجتماعى آنها است. اين كودكان به اين دليل كه نمىتوانند به طور خود به خودى و بدون كمك ديكران مهارتهاى شناختى و ارتباطى را بياموزند نيازمند نشانههاى موقعيتى،

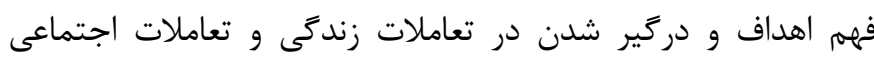

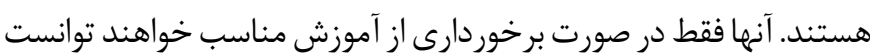
همانند همسالان عادى خود به برخى از سطوح اكتسابى مهارتهاى

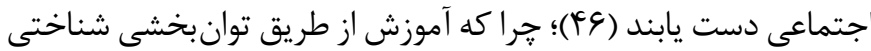
مبتنى بر حافظه موجب بهبود مشكلات رفتارى و ارتقاى حافظه فعال دانشآموزان با آسيب شنوايى مى گردد. از اين رو، فراهمسازى امكانات
افراد با آسيب شنوايى (rr)؛ Pérez-Martín و همكاران در خصوص اثربخشى توانبخشى شناختى بر بهبود عملكرد حافظه فعال بيماران

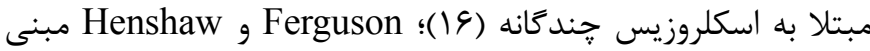
بر اثربخشى آموزش و توانبخشى شنيدارى بر بهبود حافظه فعال، توجه

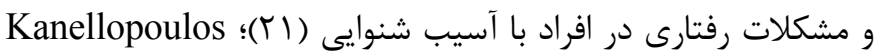
و همكاران در خصوص تاثير مثبت و معنادار توانبخشى شناختى بر مشكلات رفتارى و حافظه فعال نوجوانان بقا يافته از لوسمى (TF)؛ Hintermair با آسيب شنوايى (9)؛ Kesler و همكاران مبنى بر اثربخشى برنامه بازتوانى شناختى آنلاين بر مهارتهاى كاركرد اجرايى سرعت يردازش،

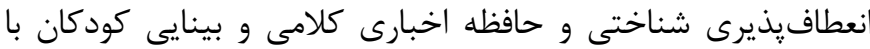
آسيب مغزى (r/)؛ Milton در خصوص اثربخشى برنامه رايانهاى

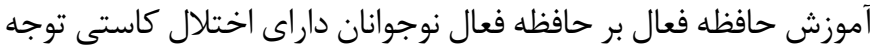

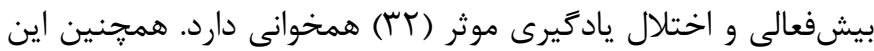

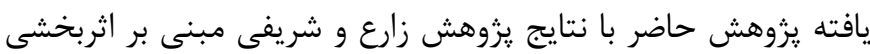
توانبخشى شناختى رايانهاى بر بهبود عملكرد حافظه فعال و آيندهنكر برك بيماران مبتلا به اسكلروزيس קندكانه (سب)؛ امانى و همكاران مبنى بر اثربخشى توانبخشى شناختى بر كاركردهاى اجرايى حافظه فعال

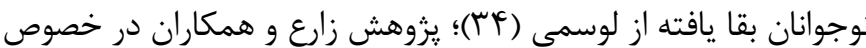
اثربخشى توانبخشى شناختى رايانهاى بر حافظه آيندهنكر بيماران دجار آسيب مغزى (r؟)؛ ارجمندنيا و همكاران مبنى بر اثربخشى مداخله

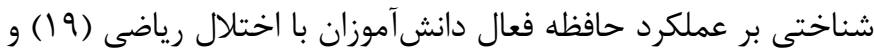
قمرى و همكاران در خصوص تاثير قابل توجه نرمافزار پِيشبرد شناختى بر كاركردهاى اجرايى، بازدارى پاسخ و حافظه فعال كودكان دهار نارساخوانى و كاستى توجه بيشفعالى (צ؟) همسو است. در تبيين اين يافته كه برنامه توانبخشى شناختى مبتنى بر حافظه سبب بهبود حافظه

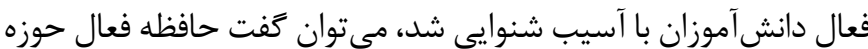

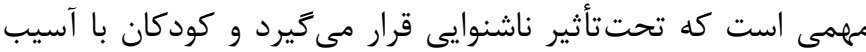
شنوايى در حافظه فعال كلامى حتى بيشتر از حافظه فعال غيركلامى دهى مشكل دارند (YI)، در حالى كه اجراى برنامه توانبخشى شناختى مىتواند هم به صورت مستقيم بر حافظه فعال تاثير مثبتى مى كذارد و

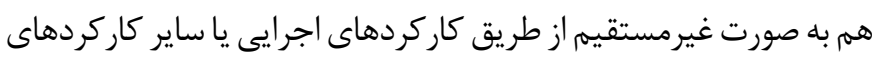

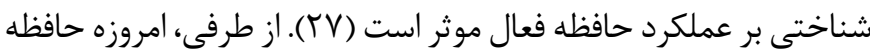

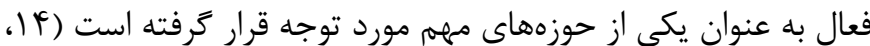

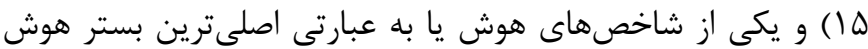

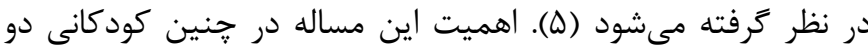
קֶندان است. جرا كه حافظه كودكان عادى با انجام فعاليتهاى روزمره 


$$
\text { كودكان با نيازهاى ويزه و خانوادههاى آنها بركزار كردد. }
$$

\section{نتيجه كيرى}

به طور كلى، نتايج يزوهش حاضر نشان داد كه برنامه توانبخشى

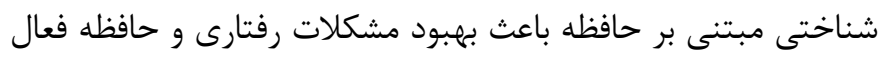

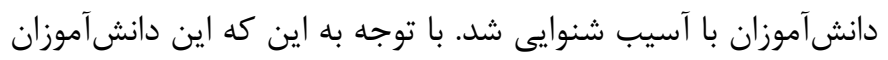
در حوزه مهارتهاى رفتارى و ظرفيت شناختى با مشكلاتى مواجه

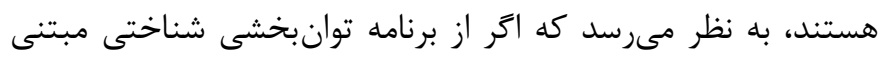
بر حافظه استفاده كنند مشكلات آنها كاهش يابد. بنابراين، برنامهريزى براى استفاده از برنامه توانبخشى شناختى مبتنى بر حافظه براى آنها

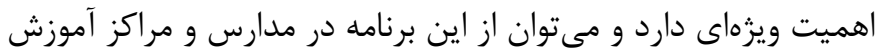

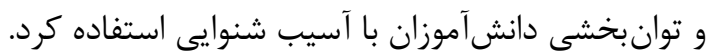

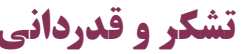

از مديريت محترم آموزش و يرورش استثنايى شهر اصفهان تشكر ودران

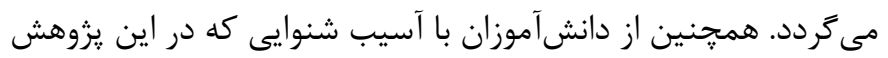
شركت داشتند، قدردانى مى شود.

\section{References}

1. Ashori M, Ghasemzadeh S. The effectiveness of mental immunization training on alexithymia, self-determination and life orientation of adolescents with hearing impairment. Journal of Psychological Studies. 2018;14(2):7-23. (Persian)

2. Kirk S, Gallagher G, Coleman MR. Educating exceptional children. 14th ed. Massachusetts:Wadsworth Publishing;2015.

3. Zaidman-Zait A, Most T, Tarrasch R, Haddad-eid E, Brand

D. The impact of childhood hearing loss on the family: Mothers' and fathers' stress and coping resources. Journal of Deaf Studies and Deaf Education. 2016;21(1):23-33.

4. Hallahan DP, Kauffman JM, Pullen PC. Exceptional learners: An introduction to special education. 14th ed. New Jersey:Pearson Education;2018.

5. Esbjørn BH, Normann N, Christiansen BM, Reinholdt-Dunne, ML. The efficacy of group metacognitive therapy for children (MCT-c) with generalized anxiety disorder: An open trial. Journal of Anxiety Disorders. 2018;53:16-21.
قابل دسترسى به منظور استفاده از برنامه توانبخشى شناختى مبتنى بر حافظه براى افراد با آسيب شنوايى ضرورى است.

محدوديتهايى را كه اين يزوهش با آن مواجه بوده است عبارتند از: اين يروهش فقط بر روى دانشآموزان با آسيب شنوايى دختر سا تا ها لها

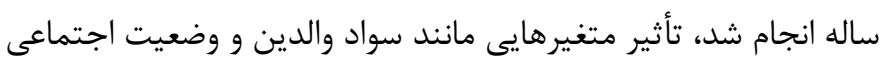
و اقتصادى آنها مورد بررسى قرار نخرفت، حجم نمونه كم بود و با توجه به محدوديت زمانى، محقق براى اجراى آزمون بيخيرى فرصتى نيافت. بنابراين بايد در تعميم نتايج احتياط كرد؛ لذا ي يشنهاد مىشود كه در يزوهشهاى آتى به سن و جنسيت آزمودنىها و ويزگى هاى شخصيتى دانشآموزان با آسيب شنوايى توجه شود، سواد والدين و وضعيت اجتماعى و اقتصادى آنها مدنظر قرار گيرد و در يزوهشهاى آتى به نوع آسيب شنوايى و وسيله كمك شنوايى توجه شود، يزوهش هاى بعدى با حجم نمونه بيشترى انجام شود و آزمون ييخيرى به عمل آيد. همجنين ريشنهاد مىشود كه آموزش توانبخشى شناختى مبتنى بر حافظه براى ساير كروههاى كود كان با نيازهاى ويزه انجام شود و اين برنامه در برنامه توانبخشى مدارس گَنجانده شود. علاوه بر اين، كارگاههاى آموزشى درباره توانبخشى شناختى مبتنى بر حافظه براى ساير گروههاى

6. Bulgan C, Ciftci A. Psychological adaptation, marital satisfaction, and academic self-efficacy of international students. Journal of International Students. 2017;7(3):687-702.

7. Ashori M, Dallalzadeh Bidgoli F. The effectiveness of play therapy based on cognitive-behavioral model: Behavioral problems and social skills of pre-school children with attention deficit hyperactivity disorder. Archives of Rehabilitation. 2018;19(2):102-115. (Persian)

8. Cook BG, Ruhaak AE. Causality and emotional or behavioral disorders: An introduction. In Garner P, Kauffman JM, Elliott JGE, editors. Sage handbook of emotional and behavioral difficulties. 2nd Ed. London:Sage Publications;2014. pp. 97-108.

9. Hintermair M. Executive functions and behavioral problems in deaf and hard-of-hearing students at general and special schools. Journal of Deaf Studies and Deaf Education. 2013;18(3):344-359.

10. Lawyer G. Deaf education and deaf culture: Lessons from Lat- 
in America. American Annals of the Deaf. 2018;162(5):486-488.

11. Okalidou A, Kitsona M, Anagnostou F, Tsoukala M, Santzakli S, Gouda S, et al. Knowledge, experience and practice of SLTs regarding (re)habilitation in deaf children with cochlear implants. International Journal of Pediatric Otorhinolaryngology. 2014;78(1):1049-1056.

12. Roy RA. Auditory working memory: A comparison study in adults with normal hearing and mild to moderate hearing loss. Global Journal of Otolaryngology. 2018;13(3):1-14.

13. Azimi M, Moradi A, Hasani J. Effectiveness of cognitive behavioral therapy for insomnia (Traditional and Internet-based) on everyday memory of people with insomnia and comorbid depression. Advances in Cognitive Sciences. 2019;20(4):2034. (Persian)

14. Dahlin KI. Working memory training and the effect on mathematical achievement in children with attention deficits and special needs. Journal of Education and Learning. 2013;2(1):118-133.

15. Dagenais E, Rouleau I, Tremblay A, Demers M, Roger É, Jobin C, et al. Role of executive functions in prospective memory in multiple sclerosis: Impact of the strength of cue-action association. Journal of Clinical and Experimental Neuropsychology. 2016;38(1):127-140.

16. Pérez-Martín MY, González-Platas M, Eguía-del Río P, Croissier-Elías C, Sosa AJ. Efficacy of a short cognitive training program in patients with multiple sclerosis. Efficacy of a short cognitive training program in patients with multiple sclerosis. Neuropsychiatric Disease and Treatment. 2017;13:245-252.

17. Adami Z, Alilou MM, Nazari MA. The comparison of emotional working memory capacity in patients with social anxiety disorder and normal subjects. Advances in Cognitive Sciences. 2019;20(4):35-45. (Persian)

18. Behrooz Sarcheshmeh S, Ashori M, Ansari Shahidi M. The effect of cognitive training on the attention rate and working memory in children with attention deficit/hyperactivity disorder. Empowering Children Journal. 2017;8(1):6-15. (Persian) 19. Arjmandnia AA, Sharifi A, Rostami R. The effectiveness of computerized cognitive training on the performance of visual-spatial working memory of students with mathematical problems. Journal of Learning Disabilities. 2014;3(4):6-24. (Persian) 20. Shin HY, Hwang HJ. Mental health of the people with hearing impairment in Korea: A population-based cross-sectional study. Korean Journal of Family Medicine. 2017;38(2):57-63.

21. Ferguson M, Henshaw H. Auditory training can improve working memory, attention, and communication in adverse conditions for adults with hearing loss. Frontiers in Psychology. 2015;6:e00556.

22. Lawrence BJ, Jayakody DM, Henshaw H, Ferguson MA, Eikelboom RH, Loftus AM, Friedland PL. Auditory and cognitive training for cognition in adults with hearing loss: A systematic review and meta-analysis. Trends in Hearing. 2018;22:1-13.

23. Kesler SR, Lacayo NJ, Jo B. A pilot study of an online cognitive rehabilitation program for executive function skills in children with cancer-related brain injury. Brain Injury. 2011;25(1):101-112.

24. Kanellopoulos A, Andersson S, Zeller B, Tamnes CK, Fjell AM, Walhovd KB, et al. Neurocognitive outcome in very long term survivors of childhood acute lymphoblastic leukemia after treatment with chemotherapy only. Pediatric Blood \& Cancer. 2016;63(1):133-138.

25. Cicerone KD, Dahlberg C, Malec JF, Langenbahn DM, Felicetti T, Kneipp S, et al. Evidence-based cognitive rehabilitation: Updated review of the literature from 1998 through 2002. Archives of Physical Medicine and Rehabilitation. 2005;86(8):1681-1692.

26. Boywitt CD, Rummel J. A diffusion model analysis of task interference effects in prospective memory. Memory \& Cognition. 2012;40(1):70-82.

27. Engle RW. Working memory and executive attention: A revisit. Perspectives on Psychological Science. 2018;13(2):190-193.

28. Hoshina A, Horie R, Giannopulu I, Sugaya M. Measurement of the effect of digital play therapy using biological information. Procedia Computer Science. 2017;112:1570-1579. 
29. Kollstad AM, Anne-Stine Dolva AS, Kleiven J. Independent and supported physical leisure activities of adolescents with Down syndrome. Ergoterapeuten; 2015;5:38-47.

30. Michel E, Roethlisberger M, Neuenschwander R, Roebers CM. Development of cognitive skills in children with motor coordination impairments at 12-month follow-up. Child Neuropsychology. 2011;17(2):151-172.

31. Jokić CS, Whitebread D. The role of self-regulatory and metacognitive competence in the motor performance difficulties of children with developmental coordination disorder: A theoretical and empirical review. Educational Psychology Review. 2011;23(1):75-98.

32. Milton H. Effects of a computerized working memory training program on attention, working memory, and academics, in adolescents with severe ADHD/LD. Psychology Journal. 2010;1(14):120-122.

33. Zare H, Sharifi AA. The effect of computerized cognitive rehabilitation on working and prospective memory function in multiple scleroses patients. Journal of Cognitive Psychology. 2017;5(1):1-10. (Persian)

34. Amani O, Mazaheri MA, Nejati V, Shamsian S. Effectiveness of cognitive rehabilitation in executive functions (attention and working memory) in adolescents survived from acute lymphoblastic leukemia with a history of chemotherapy: A randomized clinical trial. Journal of Mazandaran University of Medical Sciences. 2017;27(147):126-138. (Persian)

35. Zare H, Sharifi AA, Hatami J. The impact of computerized cognitive rehabilitation on prospective memory in patients with traumatic brain injury. Journal of Applied Psychology. 2015;1(33):63-77. (Persian)

36. Ghamari Givi H, Narimani M, Mahmoodi H. The effectiveness of cognition-promoting software on executive functions, response inhibition and working memory of children with dyslexia and attention deficit/hyperactivity. Journal of Learning Disabilities. 2012;3(2):98-115. (Persian)

37. Gall M, Borg W, Gall J. Quantitative and qualitative methods of research in psychology and educational science. Nasr A, Arizi
H, Abolghasemi M, Pakseresht MJ, Kiamanesh A, Bagheri Kh, et al. (Translators). 1th ed. Tehran:Samt;2003.pp. 189-190. (Persian) 38. Sholberg MM, Mateer CA. Cognitive rehabilitation: An integrative neuropsychological approach. New York:The Guilford press;2001.

39. Bashi Abdolabadi H, Pilevar S, Saram AA. The effect of cognitive rehabilitation on cognitive function, memory, depression, and anxiety in patients with multiple sclerosis. Shefaye Khatam. 2018;4(3):28-40. (Persian)

40. Achenbach TM, Rescorla LA. Manual for the ASEBA school-age forms \& profiles. Burlingron, VT:University of Vermont, Research Center of Children, Youth \& Families;2001.

41. Yazdkhasti F, Oreyzi H. Standardization of child, parent and teacher's forms of Child Behavior Checklist in the city of Isfahan. Iranian Journal of Psychiatry and Clinical Psychology. 2011;17(1):60-70. (Persian)

42. Pickering S, Gathercole S. Working memory test battery for children (WMTB-C) manual. London:Psychological Corporation;2001.

43. Arjmandnia AA. Working memory test battery for children (WMTB-C). 1st ed. Tehran:Roshd-e Farhang;2017. (Persian) 44. O'Connor B, Spencer FH, Patton WA. The role of working memory in relation to cognitive functioning in children. Australian Journal of Psychology. 2003;55:213-222.

45. Santomauro D, Sheffield J, Sofronoff K. Investigations into emotion regulation difficulties among adolescents and young adults with autism spectrum disorder: A qualitative study. Journal of Intellectual \& Developmental Disability. 2017;42(3):275-284.

46. Ashori M, Jalil-Abkenr SS. Students with special needs and inclusive education. 1st ed. Tehran:Roshd-e Farhang;2016. (Persian)

47. Zare H. The effect of computerized cognitive rehabilitation on everyday memory function in multiple sclerosis patients. Advances in Cognitive Sciences. 2019;20(4):1-9. (Persian)

48. Barkley RA. Attention-deficit hyperactivity disorder: A handbook for diagnosis and treatment. 3rd ed. New York:Guilford Press;2006. 